\title{
Mercury enrichment and isotope compositions in the Ediacaran Doushantuo Formation
}

\author{
WANG ZHENG ${ }^{1 *}$, SWAPAN SAHOO ${ }^{2}$, ANWEN ZHOU ${ }^{1}$, \\ YAQIU ZHAO ${ }^{1}$, YUANMING ZHANG ${ }^{1}$ \\ ${ }^{1}$ Institute of Surface-Earth System Science, Tianjin \\ University, Tianjin, China (*zhengw3@tju.edu.cn) \\ ${ }^{2}$ Equinor US
}

The Ediacaran Period ( $635-542$ million years ago) was a critical time during the Earth history, marked by the emergence and diversification of complex metazoans. The rise and decline of Ediacaran biota have been linked to changes of ocean redox conditions, which have been suggested to be highly dynamic with multipe ocean oxygenation events in a predominantly anoxic global ocean. However, the tempo and cause of the redox evolution in the Ediacaran ocean are still under debate. Here we report the concentration and stable isotope compositions of mercury $(\mathrm{Hg})$ in black shales of the Ediacaran Doushantuo Formation of South China. Hg enrichment in ancient sedimentary rocks is often caused by large volcanic acitivities or local anoxic conditions that favor the deposition of organic matter or sulfide minerals. In addition, $\mathrm{Hg}$ isotopes provide a powerful tool for tracing the source of $\mathrm{Hg}$. Therefore, the goal of this study is to futher constrain the redox conditions of the Ediacaran ocean and the possible influence of volcanism using $\mathrm{Hg}$ concentration and isotope compositions.

We analyzed $\mathrm{Hg}$ concentration in four Doushantuo sections deposited on the continental slope of the Nanhua Basin. Many samples in all sections show extremely high $\mathrm{Hg}$ enrichment, particularly the $\sim 551$ aged Member IV shales (as high as 4000ppb). This $\mathrm{Hg}$ level exceeds those reported for Phanerozic mass extinctions, which are believed to be caused by large igneous provinces (LIPs). However, unlike the typical LIPs associated $\mathrm{Hg}$ enrichment, the Doushantuo shales do not show significant peaks in the TOC-normalized $\mathrm{Hg}(\mathrm{Hg} / \mathrm{TOC})$. Most sections show strong positive correlation between TOC and $\mathrm{Hg}$, suggesting that the $\mathrm{Hg}$ enrichment was associated with the burial of organic matter. We suggest that the high Hg level in Doushantuo member IV likely reflects globally elevated atmospheric $\mathrm{Hg}$ concentration as a result of remote LIPs. Locally anoxic/euxinic conditions as indicated by other redox proxies (e.g., Fe speciation) further enhanced the scavenging of $\mathrm{Hg}$ from seawater by organic burial. Measurement of $\mathrm{Hg}$ isotopes is underway to further constrain the source of $\mathrm{Hg}$ and the influence of volcanism on redox conditions of the Ediacaran ocean. 